It thus seems clear that the Temangan fissure constitutes part of a major structural element in Malaya, running in a NNW-SSE direction for more than 100 miles. Possibly this is of the nature of a wrench fault, comparable in scale to the great Bok Bak fault recently recognized in the country (Burton, 1965, 1967).

\title{
REFERENCES
}

AleXander, J. B., 1965. Geological Map of Malaya, 6th edition (Diamond Jubilee). Survey Dept. Malaya No. 67-1964, Geol. Survey Drawing 63-288.

Burton, C. K., 1965. Wrench Faulting in Malaya. J. Geol., 73, 781-798.

1967. Wrench Faulting in Malaya: A Reply. J. Geol., 75, 128-9.

(in manuscript). The Geology and Mineral Resources of the Area covered by New Series Map Sheet 130, Johore. Mem. geol. Surv. Malaysia (Malaya).

Ingham, F. T., 1948. Geological Map of Malaya, 1948. Surv. Dept. Fed. Malaya.

MACDonald, S. (in manuscript). The Geology and Mineral Resources of North Kelantan and North Trengganu. Mem. geol. Surv. Malaysia (Malaya).

Department of Geology, Faculty of SCience,

C. K. Burton.

CHULALONGKORN UNIVERSITY,

BANGKOK, THAILAND.

19 th May, 1966.

\section{HYALOSTELIA ZITTEL AND THE HETERACTINELLIDA}

SIR,-In Dr. B. K. Holdsworth's recent paper (1967) on the dolomitization of siliceous microfossils, the sponge Hyalostelia Zittel is referred to the Heteractinellida, which are described as " an exclusively siliceous group". The nature of their spicules is actually unknown, and grounds exist for thinking them more probably calcareous than siliceous. On the other hand, Hyalostelia is not a member of the Heteractinellida.

The spicules of Heteractinellida were regarded as siliceous by Hinde (1887-1912), but no modern species are known to confirm this. Specimens may occur in calcareous or siliceous preservation, and Wewokella Girty is apparently always calcareous. Finks (1960) has concluded that true heteractinellids are Calcarea. There are no grounds for thinking them related to the Hexactinellida, with which they were grouped by de Laubenfels (1955) in his Hyalospongea, because the characteristic spicules (polyaenes, neoasters) have no counterparts in any known hexactinellid. De Laubenfels stated (1955, p. 93) that " most families of Recent hyalosponges" contain polyactinal microscleres; but, in fact, no such spicules are known from any hexactinellid yet described. The strongest suggestion that the spicules were siliceous is thus the resemblance of polyaenes to demosponge triaenes and their variants (cf. Reid, 1959) ; but this is not conclusive. In contrast, formation of the rays as separate units, now found only in Calcarea, is implied by the suturing of rays at their bases in Chancelloria Walcott (Reid, 1959) and Allonnia Doré and Reid. In addition, a similar suturing, with the rays sharply faceted at their bases as in Allonnia (Doré and Reid, 1965, fig. 1), occurs in triactinal spicules of the living calcareous sponge Leucettusa Dendy $(1929$, pl. 1, figs. $7,10,12)$. Nothing of the kind is recorded from spicules of Hexactinellida or Demospongia. The dependence of the suturing on the mode of formation of the spicules must also rank this evidence higher than any simple resemblance in shape.

This, however, need not conflict with Dr. Holdsworth's conclusions, because Hyalostelia is not heteractinellid, but hexactinellid. When Young and Young (1877) described the type species $H$. smithii as a Hyalonema, 
loose polyaene spicules which were also described were wrongly attributed to $H$. smithii in the figure caption, though not in the text. Zittel appears to have relied on the incorrect caption, since his diagnosis $(1880$, p. 185) wrongly attributes forms with 6-8 rays to Hyalostelia. Hinde's recognition that the polyaenes do not belong to $H$. smithii, but to a Tholiasterella (1887-1912, pp. 158-160, 169), was apparently missed by de Laubenfels (1955), whose treatment of Hyalostelia follows Zittel. Topotype material of H. smithii collected by the writer confirms Hinde's description of the species as a true hexactinellid, and the spicules can be taken as siliceous accordingly.

\section{REFERENCES}

Dendy, A., 1929. Porifera. Non-Antarctic sponges. Brit. Antarct. (Terra Nova) Exped. 1910, Zool., 6, 269-392.

Doré, F., and R. E. H. Reid, 1965. Allonnia tripodophora nov, gen., nov. sp., nouvelle éponge du Cambrien inférieur de Carteret (Manche). C.R. Soc. géol. Fr., 1965, $20-21$.

Finks, R. M., 1960. Late Paleozoic sponge faunas of the Texas Region. The siliceous sponges. Bull. Am. Mus. nat. Hist., 120, 1.

Laubenfels, M. W. de, 1955. Porifera. Treatise on Invertebrate Paleontology, Part E, Archaeocyatha and Porifera. Geol. Soc. America and Kansas University Press. pp. 21-122.

Hinde, G. J., 1887-1912. A monograph of the British Fossil Sponges. Palaeontogr. Soc. [Monogr.].

Holdsworth, B. K., 1967 . Dolomitization of Siliceous Microfossils in Namurian Concretionary Limestones. Geol. Mag., 104, 148-154.

ReID, R. E. H., 1959. Occurrence of Chancelloria Walcott in the Comley Limestone. Geol. Mag., 96, 261-2.

Young, J., and J. Young, 1877. On a Carboniferous Hyalonema and other sponges from Ayrshire. Ann. Mag. Nat. Hist., s. 4, 20, 425-432.

Zirtel, K. A. von, 1880. Handbuch der Palaeontologie. R. Oldenbourg, Munich and Leipzig.

Department of Geology,

R. E. H. REID.

THE QUEEN'S UNIVERSTTY OF BELFAST,

BELFAST, NORTHERN IRELAND.

1st June, 1967.

\section{WATER RESOURCES}

SIR,-In his review of the " Geology of the Country around Nantwich and Whitchurch" published in the Geological Magazine for March-April, 1967 (104, (2) 197-198) Dr. P. E. Kent states “ . . . water is now outside the I.G.S.'s responsibilities but it is not obvious that there will be any other place where the relationship of underground water to the geology is considered ". I should be glad of the opportunity of advising your readers as to the present position of ground-water research at the I.G.S.

The Water Department of the Institute, formed in 1935, was concerned before and during the war with establishing its well record collections and with day-to-day water supply development problems ; little basic research work was undertaken. In the post-war years, the increasing use of ground-water resources in the U.K. led to a change of emphasis towards estimation of ground-water resources and regional management problems, again at the expense of basic research. The implementation of the Water Resources Act, 1963 , and the associated transfer of staff from the Institute to form the nucleus of the present Geology Division of the Water Resources Board, has resulted in the transfer of ground-water management and development problems in England and Wales to the River Authorities and to the Board. The hydrogeological staff of I.G.S. has been replaced and the Institute is mounting a comprehensive programme of research into the occurrence of ground water, complementary to such consideration as takes place at the Board. Indeed, publication of the Water Supply Papers of the Geological Survey of Great 